\title{
Effects of bypass diode configurations to the maximum power of photovoltaic module
}

\author{
J. C. Teo ${ }^{\mathrm{a}}$, Rodney H. G. Tan ${ }^{\mathrm{a}}$, V. H. Mok ${ }^{\mathrm{a}}$, Vigna K. Ramachandaramurthy ${ }^{\mathrm{b}}$, C. \\ K. $\operatorname{Tan}^{\mathrm{c} *}$ \\ ${ }^{a}$ UCSI University, No.1, Jalan Menara Gading, Kuala Lumpur 56000, Malaysia \\ ${ }^{b}$ Universiti Tenaga Nasional, Jalan Ikram-Uniten, Selangor 43000, Malaysia \\ ${ }^{c}$ University Of Malaya, Jalan Universiti, Kuala Lumpur 50603, Malaysia
}

\begin{abstract}
Effects of bypass diode configurations to the maximum power of photovoltaic module are presented. The impacts of one, two and three bypass diodes configurations to the photovoltaic module are investigated using simulation approach. Simulink models are developed to perform all the simulations in this investigation. In the investigation, various shading patterns are applied to one, two and three bypass diodes configurations to investigate the impact of bypass diode configuration to the maximum power of photovoltaic module. Simulation results show that the bypass diode configurations doesn't affect the maximum power of the photovoltaic module under certain shading conditions. The comparison study among one, two and three bypass diodes configurations show a greater quantity of bypass diode in a photovoltaic module doesn't guarantee better performance during partial shading conditions.
\end{abstract}

Keywords: Photovoltaic module, bypass diode, partial shading

\section{Introduction}

Photovoltaic power system has become more and more popular due to its environmental friendly nature. Photovoltaic module is the most basic component in a photovoltaic system, which is used to convert solar energy to electrical power.

To harvest maximum power from a photovoltaic module, $\mathrm{P}-\mathrm{V}$ characteristics curve of the photovoltaic module must be determined and understood in the first place [1]. Fig. 1 shows P-V characteristics curve of a typical photovoltaic module. The remarked point on the $\mathrm{P}-\mathrm{V}$ characteristics curve is the highest point of the P-V characteristics which represent the maximum power delivered by photovoltaic module [2].

A typical photovoltaic module consists of several series connected solar cells as illustrated in Fig. 2 [3]. Due to the series connection, every solar cell in the photovoltaic module is forced to deliver equal electrical current.

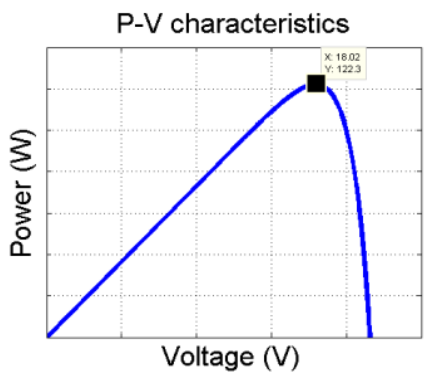

Fig. 1. P-V characteristics of photovoltaic module.

\footnotetext{
* Manuscript received July 11, 2017 ; revised October 24, 2017.

Corresponding author. Tel.: +60173078955; E-mail address: rodneytan72@ hotmail.com.

doi: $10.12720 /$ sgce.6.4.225-232
} 


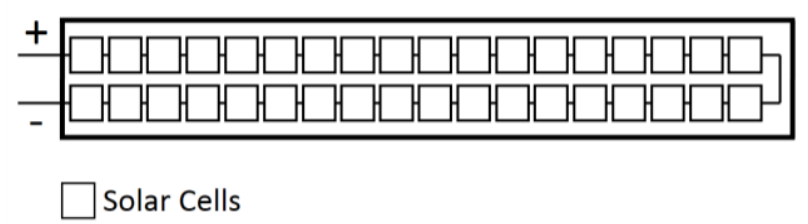

Fig. 2. Photovoltaic module.

During partial shading, shaded solar cells in the photovoltaic module produce lower electrical current. As a result, shaded solar cells force the unshaded solar cells to deliver low electrical current even if the unshaded solar cells are capable to produce higher electrical current. This drastically reduces the performance of the photovoltaic module.

Moreover, the lower irradiated solar cells in the photovoltaic module become reverse biased and dissipate power generated by higher irradiated solar cells. As a result, the lower irradiated solar cells become overheated and hot spots appear on the solar cell [4]. The solar cell will be damaged if the power dissipated exceed maximum power that can be sustained by the solar cell.

Considering on this issues, manufacturers implement bypass diodes on photovoltaic modules to bypass the lower shaded solar cell during uneven irradiation conditions. When bypass diodes conduct, they introduce certain voltage drop and consume power generated by the photovoltaic module. Hence, it brings impact to the maximum power delivered by the photovoltaic modules [5].

Since the bypass diode brings impact to the maximum power of the photovoltaic module, it is essential to study the impact of bypass diode to the maximum power of photovoltaic module. There are several types of bypass diode configurations usually implemented on photovoltaic module including one, two or three bypass diodes configurations. Each bypass diode configuration brings different impact to the maximum power of photovoltaic module. Hence, it is essential to study the impact of bypass diode configurations to the maximum power of photovoltaic module.

In 2009, S. Silvestre et al. [6] have studied the P-V characteristics of photovoltaic modules that have different bypass diode configuration including two non-overlapping bypass diodes and two overlapping bypass diodes using simulation approach.

In 2014, Huiying Zheng et al. [7] have studied the P-V characteristic of a photovoltaic module when a solar cell in the photovoltaic module is shaded with a certain degree. However, the study is conducted on a photovoltaic module without bypass diode.

The most common type of bypass diode configurations on a photovoltaic module are one, two and three non-overlapping bypass diodes configurations. However, there is no comparative study conducted previously among these three types of bypass diode configurations on photovoltaic module.

Considering these issues, it is reasonable to conduct a comparative study among photovoltaic modules that have one, two and three bypass diodes configurations. This paper presents a comparative study among photovoltaic modules that have one, two and three non-overlapping bypass diode using simulation approach.

\section{Methodology}

A typical photovoltaic module consists of 36 series connected solar cell. Hence, a photovoltaic module with 36 solar cells is chosen for this investigation. It is having open circuit voltage of $21.6 \mathrm{~V}$, short circuit current of $7.34 \mathrm{~A}$, ideality factor of 1.5 , series resistance of $0 \mathrm{ohm}$ and cell temperature, $\mathrm{T}=25 \mathrm{oC}$ are used for all the case studies in this investigation.

Table 1 shows all the case studies carried out in this investigation. All the case studies are carried out using simulation approach. The simulations are performed to determine P-V characteristics and maximum power of photovoltaic module consists of 36 series connected solar cells under different bypass diode configurations. In this photovoltaic module, 18 cells are grouped as the shaded group and another 18 cells 
are grouped as the unshaded group as illustrated in Fig. 3.

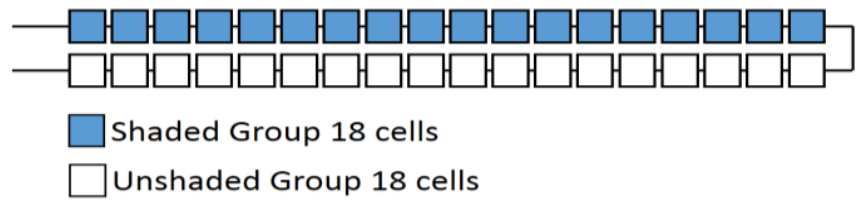

Fig. 3. Photovoltaic module used in the investigation.

Table 1. Case studies carried out

\begin{tabular}{|c|c|c|c|c|}
\hline \multirow[t]{2}{*}{ Case Studies } & \multirow[t]{2}{*}{$\begin{array}{l}\text { Bypass Diode } \\
\text { Configuration }\end{array}$} & \multicolumn{2}{|c|}{$\begin{array}{l}\text { Solar Cell Irradiance } \\
\left(\mathrm{w} / \mathrm{m}^{2}\right)\end{array}$} & \multirow{2}{*}{$\begin{array}{l}\text { Shading } \\
\text { Factor } \\
\left(F_{S}\right)\end{array}$} \\
\hline & & $\begin{array}{l}\text { Unshaded } \\
\text { group } \\
(18 \text { Cells })\end{array}$ & $\begin{array}{l}\text { Shaded } \\
\text { Group } \\
\text { (18 Cells) }\end{array}$ & \\
\hline Case 1 & \multirow{6}{*}{$\begin{array}{l}\text { One Bypass } \\
\text { Diode }\end{array}$} & 1000 & 0 & 0 \\
\hline Case 2 & & 1000 & 200 & 0.2 \\
\hline Case 3 & & 1000 & 400 & 0.4 \\
\hline Case 4 & & 1000 & 600 & 0.6 \\
\hline Case 5 & & 1000 & 800 & 0.8 \\
\hline Case 6 & & 1000 & 1000 & 1 \\
\hline Case 7 & \multirow{6}{*}{$\begin{array}{l}\text { Two Bypass } \\
\text { Diodes }\end{array}$} & 1000 & 0 & 0 \\
\hline Case 8 & & 1000 & 200 & 0.2 \\
\hline Case 9 & & 1000 & 400 & 0.4 \\
\hline Case 10 & & 1000 & 600 & 0.6 \\
\hline Case 11 & & 1000 & 800 & 0.8 \\
\hline Case 12 & & 1000 & 1000 & 1 \\
\hline Case 13 & \multirow{6}{*}{$\begin{array}{l}\text { Three Bypass } \\
\text { Diodes }\end{array}$} & 1000 & 0 & 0 \\
\hline Case 14 & & 1000 & 200 & 0.2 \\
\hline Case 15 & & 1000 & 400 & 0.4 \\
\hline Case 16 & & 1000 & 600 & 0.6 \\
\hline Case 17 & & 1000 & 800 & 0.8 \\
\hline Case 18 & & 1000 & 1000 & 1 \\
\hline
\end{tabular}

Shading factor, FS shown in Table 1 is defined in (1), where IT,S is the irradiance on the shaded surface and the IT is the irradiance on the unshaded surface[8].

$$
F_{S} \quad \frac{I_{T, S}}{I_{T}}
$$

One, two and three bypass diode configurations used in Table 1 are shown in Fig. 4, Fig. 5 and Fig. 6 respectively. The bypass diode connected across 36 solar cells for one bypass diode configuration. For two bypass diode configuration, each bypass diode cover 18 solar cells. For three bypass diodes configuration, each bypass diode cover 12 solar cells.

\section{One Bypass Diode}

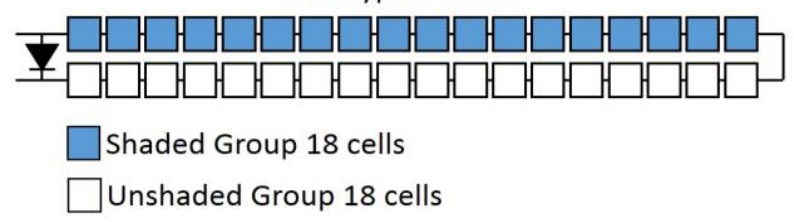

Fig. 4. Photovoltaic module - one bypass diode. 


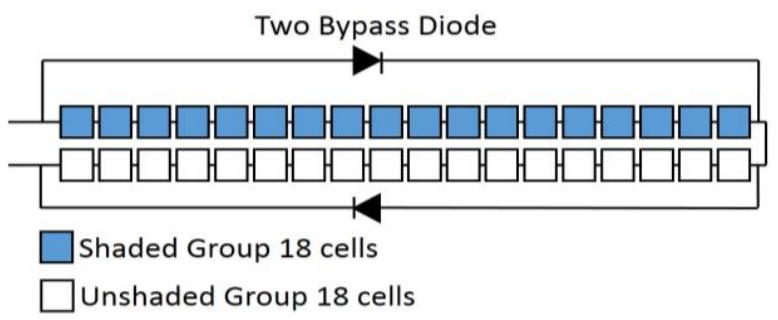

Fig. 5. Photovoltaic module - two bypass diode.

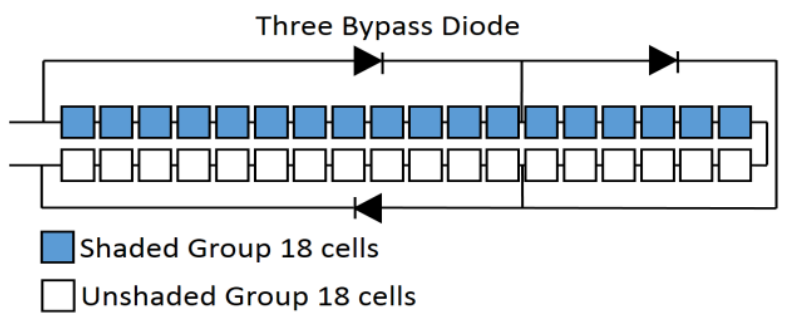

Fig. 6. Photovoltaic module - three bypass diode.

Photovoltaic module models are developed in Simulink software to perform simulations for case studies in Table 1. Solar cell block from SimElectronics block set is used as the base model to develop photovoltaic module models. The solar cell block is configured to 5 parameter configuration which is defined in (2) and (3).

$$
\begin{aligned}
& I=I_{P H}-I_{O} \exp \left(\frac{V+I R_{S}}{N_{S} V_{T}}-1\right) \\
& V_{T}=\frac{A k T}{q}
\end{aligned}
$$

$I$ is the output current, $I_{P H}$ is the photo-generated current, $I_{O}$ is the diode saturation current, $V$ is the output voltage, $R_{S}$ is the series resistance, $N_{S}$ is the number of cells, $V_{T}$ is the junction thermal voltage, $A$ is the ideality factor, $k$ is the Boltzman constant $(1.3806503 \times 10-23 \mathrm{~J} / \mathrm{K}), T$ is the cell temperature and $q$ is the electron charge $(1.6021765 \times 10-19 \mathrm{C})$.

Fig. 7 shows photovoltaic module model developed simulate photovoltaic module with one bypass diode configuration. The simulations are executed using ode23t solver. During simulations, the Controlled Current Source block sweeps the output current and the Voltage Sensor block measures the output voltage of the photovoltaic module. The Product block is used to multiply the output voltage and output current of the photovoltaic module to obtain the output power of the photovoltaic module. The To Workspace block sends the output power and output voltage of photovoltaic module to MATLAB workspace to plot P-V characteristics curve.

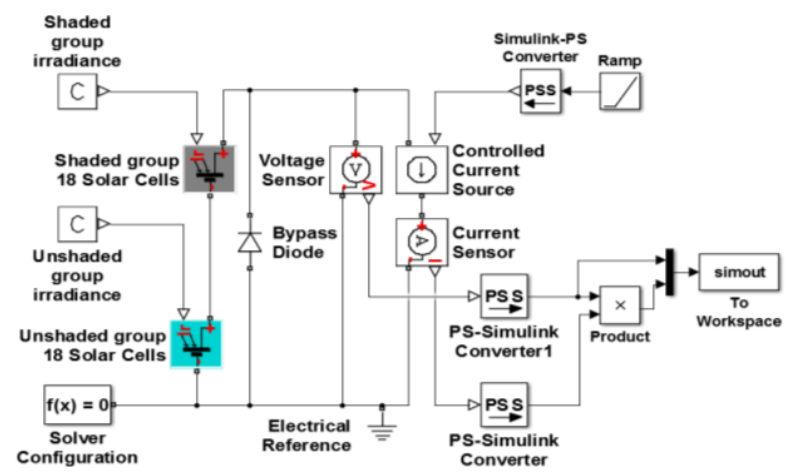

Fig. 7. Photovoltaic module model (one bypass diode). 
Fig. 8 shows photovoltaic module model developed using Solar Cell block to simulate photovoltaic module with two bypass diodes configuration. The simulations are executed using similar control flow as photovoltaic module model in Fig. 5.

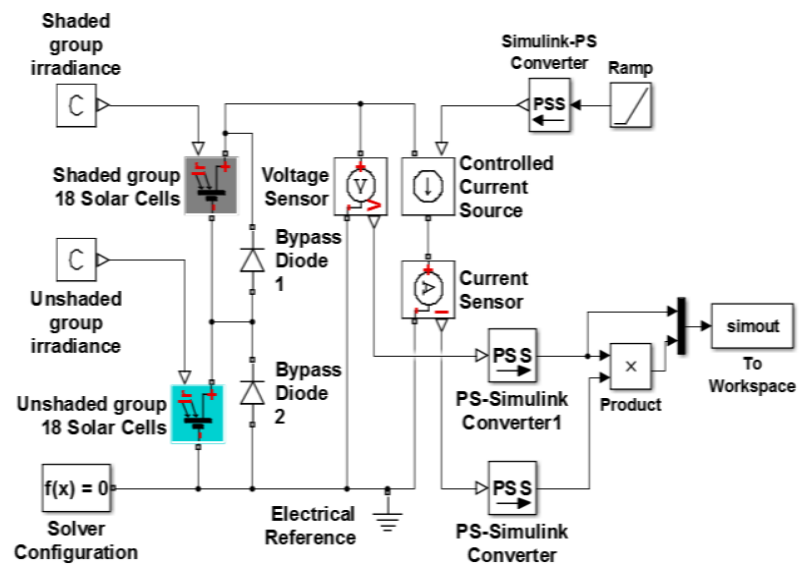

Fig. 8. Photovoltaic module model (two bypass diodes).

Fig. 9 shows photovoltaic module model developed to simulate photovoltaic module with three bypass diodes configuration using similar control flow as Fig. 5 and Fig. 6. Shaded group 1, shaded group 2 and shaded group 3 block contain 6 solar cells respectively. These three shaded group blocks represent shaded group (18 solar cells) in Table 1. Unshaded group 1, unshaded group 2 and unshaded group 3 block contains 6 solar cells respectively. These three unshaded group blocks represent the unshaded group (18 solar cells) in Table 1.

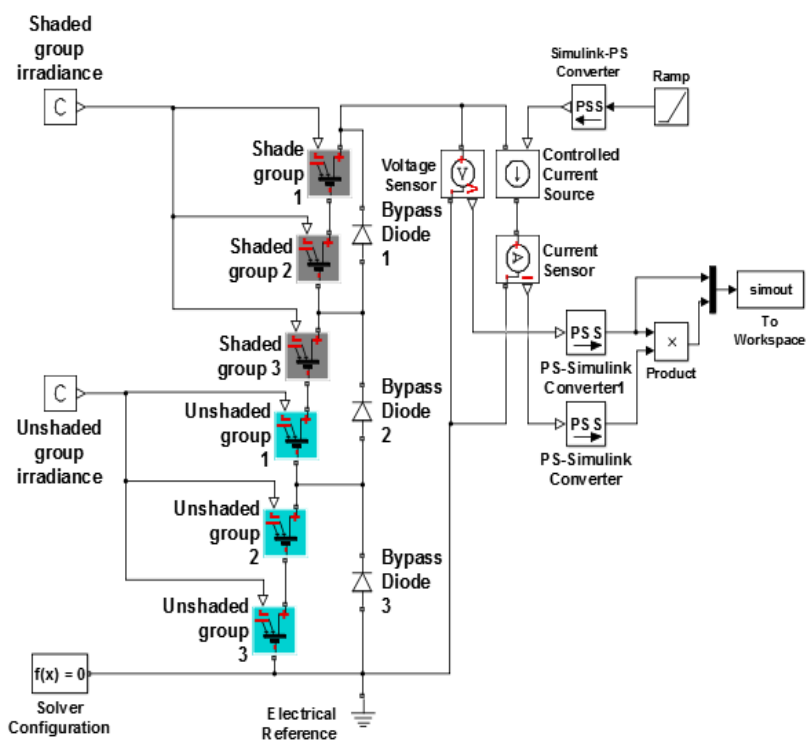

Fig. 9. Photovoltaic module model (three bypass diodes).

\section{Results and Discussion}

Simulated P-V characteristics curve for one, two and three bypass diodes configurations are shown in Fig. 10, Fig. 11 and Fig. 12 respectively. For one bypass diode configuration, P-V characteristics curve for zero shading factor is not shown on the graph. It is because the photovoltaic module unable to 
generate power at any voltages.

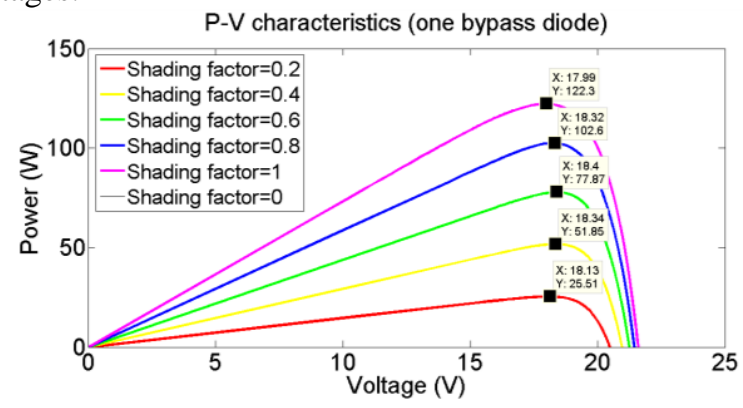

Fig. 10. P-V characteristics curve (one bypass diode).

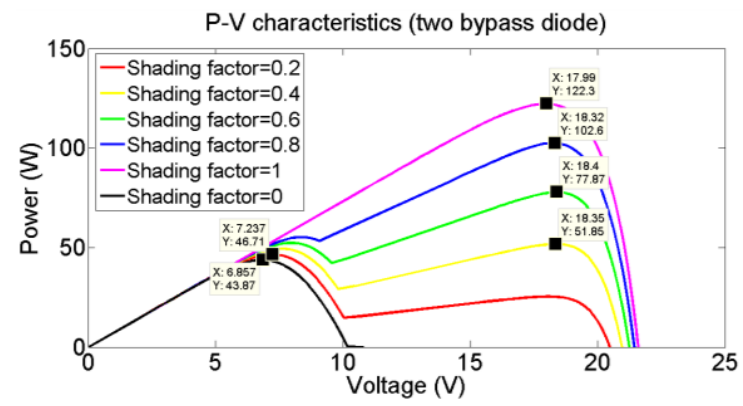

Fig. 11. P-V characteristics curve (two bypass diode).

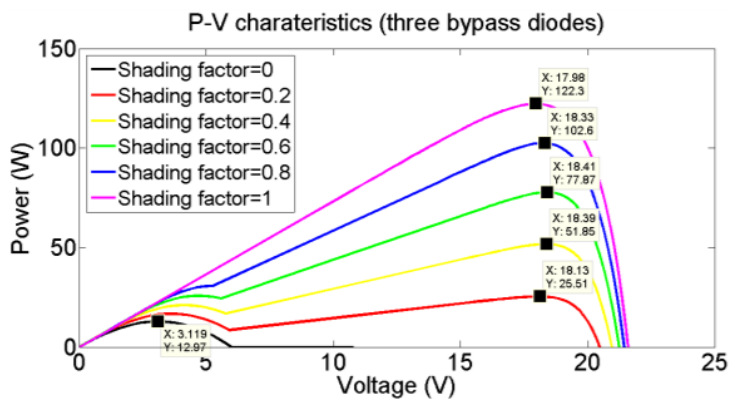

Fig. 12. P-V characteristics curve (three bypass diode).

It is observed that the P-V characteristics curves of one bypass diode configurations exhibit single peak for all shading factors (Fig. 10) unlike multiple peaks occurrence in P-V characteristics of two and three bypass diode configurations (Fig. 11 and Fig. 12). This is because the shaded group cells are not bypassed from the unshaded group cells, hence the unshaded group cells are forced to have same P-V characteristics as shaded group cells.

Multiple peaks are observed in P-V characteristics curves of two and three bypass diode configurations when shading factor is 0.2 to 0.8 . It is because the bypass diodes are activated which bypasses the shaded group cells and allow the unshaded group cells to have different $\mathrm{P}-\mathrm{V}$ characteristics with the shaded group cells.

It is observed that the P-V characteristics curves exhibit single peak when shading factor is 1 regardless one, two or three bypass diode configurations. It is because the shaded solar cells and unshaded solar cells are receiving the same irradiance, so both shaded and unshaded solar cells having same P-V characteristics.

The remarked points in Fig. 10, Fig. 11 and Fig. 12 are the highest points of P-V characteristics curves which represent the maximum power of photovoltaic module for different shading factors. The maximum powers are located at higher voltage region $(15-25 \mathrm{~V})$ of $\mathrm{P}-\mathrm{V}$ characteristics curve for one bypass diode 
configuration.

However, other behaviors are observed in two and three bypass diodes configurations. In two bypass diodes (Fig. 11), the location of maximum power changed to lower voltage region $(0-15 \mathrm{~V})$ of P-V characteristics curve when shading factor is lower than 0.4. In three bypass diodes (Fig. 12), the location of maximum power changed to lower voltage region of $\mathrm{P}-\mathrm{V}$ characteristics curve when shading factor is lower than 0.2 .

Table 2 shows maximum powers of one, two and three bypass diodes configurations under different shading factors obtained from Fig. 10, Fig. 11 and Fig. 12. Fig. 13 illustrates the relationship between maximum power and shading factors for different bypass diode configurations that plotted using Table 2 . When shading factor is above 0.4 , all three configurations having same maximum power. This show that the maximum power of photovoltaic module is not affected by the bypass diodes configuration anymore when shading factor is higher than 0.4.

Table 2. Maximum powers of photovoltaic module

\begin{tabular}{|c|c|c|c|}
\hline \multirow{4}{*}{$\begin{array}{l}\text { Shading } \\
\text { Factor } \\
\left(F_{S}\right)\end{array}$} & \multicolumn{3}{|c|}{ Maximum Power $(\mathrm{W})$} \\
\hline & One & Two & Three \\
\hline & Bypass Diode & Bypass Diodes & Bypass Diodes \\
\hline & Configuration & Configuration & Configuration \\
\hline 0 & 0 & 43.87 & 12.97 \\
\hline 0.2 & 25.51 & 46.71 & 25.51 \\
\hline 0.4 & 51.85 & 51.85 & 51.85 \\
\hline 0.6 & 77.87 & 77.87 & 77.87 \\
\hline 0.8 & 102.6 & 102.6 & 102.6 \\
\hline 1 & 122.3 & 122.3 & 122.3 \\
\hline
\end{tabular}

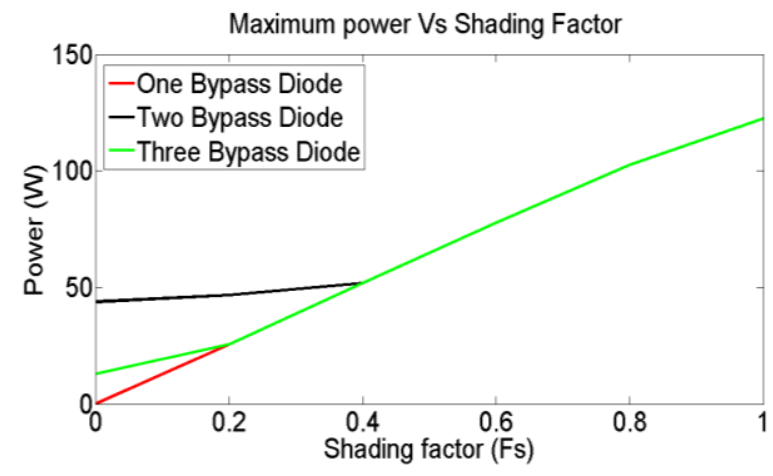

Fig. 13. Maximum power versus shading factor.

When shading factor is lower than 0.4 , three bypass diodes configuration has lower maximum power compared to two bypass diodes configuration. This shows that the two bypass diode outperform the three bypass diode when shading factor is lower than 0.4 . Hence, a greater quantity of bypass diode doesn't guarantee better performance during partial shading conditions.

\section{Conclusions}

A comparative study among photovoltaic modules that have one, two and three bypass diodes configurations using simulation approach is presented. P-V characteristics of one, two and three bypass diode configurations have been simulated with various shading patterns. A greater quantity of bypass diodes is commonly believed to have better performance during partial shading conditions. Thus, other researchers proposed two and three bypass diodes configurations apart from one bypass diode 
configuration. However, the investigation shows that two bypass diodes configuration outperformed three bypass diodes configuration under certain partial shading conditions. Hence, a greater quantity of bypass diodes doesn't guarantee better performance. It is because the impacts of bypass diode configurations are determined by the shading pattern that experienced by the photovoltaic module at the particular time.

\section{Acknowledgement}

This project is funded by the Ministry of Education Malaysia under Fundamental Research Grant Scheme, Project code FRGS/1/2015/TK07/UCSI/02/1.

\section{References}

[1] Malathy S, Ramaprabha R. Comprehensive analysis on the role of array size and configuration on energy yield of photovoltaic systems under shaded conditions. Renewable and Sustainable Energy Reviews, 2015; 49:672-679.

[2] Maghami MR, Hizam H, et al.. Power loss due to soiling on solar panel: a review. Renewable and Sustainable Energy Reviews, 2016; 59:1307-1316.

[3] Deline C, Dobos A, Janzou S, Meydbray J, Donovan M. A simplified model of uniform shading in large photovoltaic arrays. Solar Energy, 2013; 96:274-282.

[4] Herrmann W, Wiesner W, Vaassen W. Hot spot investigations on PV modules-new concepts for a test standard and consequences for module design with respect to bypass diodes. Presented at: 1997 IEEE PVSC.

[5] Bauwens P, Doutreloigne J. Reducing partial shading power loss with an integrated smart bypass. Solar Energy, 2014; 103:134-142.

[6] Silvestre S, Boronat A, Chouder A. Study of bypass diodes configuration on PV modules. Applied Energy, 2009; 86:16321640.

[7] Zheng H, Li S, Challooand R, Proano J. Shading and bypass diode impacts to energy extraction of PV arrays under different converter configurations. Renewable Energy, 2014; 68:58-66.

[8] Cascone Y, Corrado V, Serra V. Calculation procedure of the shading factor under complex boundary conditions. Solar Energy. 2011; 85:2524-2539. 